\title{
Monitoring of urine nitric oxide (NO) related substrates and immunological competence in hematological malignancy ${ }^{\star}$
}

\author{
Junko Tanaka ${ }^{\bowtie}$, Kunio Koshimura, Michihiro Tsumori, Yoshio Murakami \\ and Yuzuru Kato
}

First Division, Department of Medicine, Shimane Medical University, Izumo, Japan

Received: 10 September, 2001; revised: 29 January, 2002; accepted: 12 February, 2002

Key words: urine nitric oxide, hematological malignancy, phytohemagglutinin, pokeweed mitogen

\begin{abstract}
It has been reported that concentrations of neopterin in the urine are changed according to the host immunological conditions. In the present study, we measured urinary concentration of neopterin in patients with malignant hematological disorders and investigated the relationship between urinary neopterin levels and laboratory indices for cellular immunity. Urine neopterin levels were correlated with serum sIL-2R levels in the patients with malignant lymphoma, and inversely correlated with lymphocyte reactivity with ConA in the patients with acute myelocytic leukemia. However, no significant correlation was observed between urine neopterin levels and lymphocyte reactivity with phytohemagglutinin and pokeweed mitogen, $\mathrm{CD} 4 / 8$ ratio, $\mathrm{CD56}{ }^{+} 16^{+}$ subset or serum IFN- $\gamma$ levels. In the patients with malignant lymphoma, parallel changes in serum sIL-2R and urine neopterin were observed. The presented results suggest that urine neopterin levels are related to the activation of $T$ cells in malignant lymphoma.
\end{abstract}

Recently, it has been revealed that nitric oxide (NO) is produced by $\mathrm{T}$ cells or macrophages [1-3], suggesting that NO is associated with cellular immunity. Tetrahydrobiopterin $\left(\mathrm{BH}_{4}\right)$, a cofactor for $\mathrm{NO}$ synthase (NOS), is produced when the cells involved in cellular immunity are activated [4, 5]. Furthermore, it has been reported that urine concentrations of neopterin, an intermediate product of $\mathrm{BH}_{4}$, changes according to immunological conditions of the host $[6,7]$. These results suggest that $\mathrm{NO}$ and $\mathrm{BH}_{4}$ are involved

\footnotetext{
${ }^{\star}$ Presented at the 8th International Symposium on Molecular Aspects of Chemotherapy, September, 2001, Gdańsk, Poland.

${ }^{凶}$ Address for all correspondence to Junko Tanaka, First Division, Department of Medicine, Shimane Medical University, 89-1 Enya-cho, Izumo 693-8501, Japan; phone: (81) 85320 2184; fax: (81) 85323 8650; e-mail: jtanaka@shimane-med.ac.jp

Abbreviations: AML, acute myelocytic leukemia; $\mathrm{BH}_{4}$, tetrahydrobiopterin; ConA, concanavalin $\mathrm{A}$; $\mathrm{ML}$, malignant lymphoma; MM, multiple myeloma; NO, nitric oxide; NOS, NO synthase; NP, neopterin; PHA, phytohemagglutinin; PWM, pokeweed mitogen; WBC, white blood cells.
} 
in cellular immunity. In the present study, we measured urinary concentrations of neopterin in patients with malignant hematological disorders and investigated the relationship between urinary neopterin levels and laboratory indices for cellular immunity.

\section{EXPERIMENTAL PROCEDURES}

Urine samples for neopterin (NP) assay were collected from two patients with malignant lymphoma (ML), three patients with acute myelocytic leukemia (AML) and two patients with multiple myeloma (MM) who were hospitalized in Shimane Medical University Hospital. Among these patients, autoperipheral blood stem cells transplantation was carried out in Cases 1 and 6. Urine samples were collected at the time of admission, pre- and post-chemotherapy, and pre- and post-transplantation. To avoid the influence of inflammation, urine samples were not collected when patients were assumed to have inflammation as diagnosed by fever and increased serum C-reactive protein. Urine sample was centrifuged at 3000 r.p.m. for $10 \mathrm{~min}$. The supernatant was stored at $-80^{\circ} \mathrm{C}$ until assayed. Urinary neopterin levels were measured according to the method of Hibiya et al. [8]. Briefly, an aliqout of the urine supernatant $(120 \mu \mathrm{l})$ was added to $60 \mu \mathrm{l}$ of $6 \mathrm{M}$ $\mathrm{HCl}$ and boiled at $100^{\circ} \mathrm{C}$ for $2 \mathrm{~h}$. Then the sample was lyophilized and reconstituted with $120 \mu \mathrm{l}$ of $50 \mathrm{mM}$ ammonium phosphate $(\mathrm{pH}$ 3.0). The mixture was centrifuged at 4200 r.p.m. for $10 \mathrm{~min}$. The supernatant was applied on HPLC with fluorescent detection (excitation: $350 \mathrm{~nm}$, emission: $455 \mathrm{~nm}$ ). As indices for cellular immunity, lymphocyte reaction with phytohemagglutinin (PHA), concanavalin A (ConA) and pokeweed mitogen (PWM) were estimated using JIMRO Fluorometric Blastformation Test (Japan Immunoresearch Laboratories Co., Ltd., Takasaki, Japan), that is measured amount of nucleic acid of reacted lymphocyte by lectin
(PHA, ConA and PWM). CD4/8 ratio and CD56 ${ }^{+} 16^{+}$cell subset were measured using flow cytometry. Soluble IL2 receptor (sIL2R) levels in the serum measured in SRL Inc. Laboratory. Serum interferon $\gamma(\mathrm{IFN}-\gamma)$ levels were estimated using ELISA assay kit (Amersham Pharmacia Biotech, Tokyo, Japan).

\section{RESULTS}

Immunological indices and urine NP levels of the patients are shown in Table 1. Serum sIL-2R levels of the patients with ML were much higher than those of the patients with AML and MM, and beyond the healthy control estimated in the Laboratory. Other immunological indices were within healthy control range and not different among the patients with ML, AML and MM. Urine NP levels did not differ among the patients with ML, AML and MM. Urine NP levels were correlated with serum sIL-2R levels in the patients with ML, but not AML or MM (Fig. 1). Regardless of the disease, urine NP levels varied markedly between samples from the same patient. The NP levels were inversely correlated with lymphocyte reactivity with ConA in the patients with AML (Fig. 2). No significant correlation was observed between urine NP levels and lymphocyte reactivity with PHA and PWM, CD4/8 ratio, $\mathrm{CD}^{+} 6^{+} 16^{+}$subset or IFN- $\gamma$ levels. In the patients with $\mathrm{ML}$, urine NP levels varied parallel to the serum sIL-2R levels (Fig. 3). In contrast, no relationship was observed between the profile of urine NP levels and lymphocyte reaction with ConA in the patients with AML.

\section{DISCUSSION}

Urine NP levels were remarkably elevated at some collection points in many patients beyond the healthy control levels [9]. Since NP is altered by immunological disorders [6, 7], it is 
Table 1. Immunological data of patients with ML, AML and MM

\begin{tabular}{|c|c|c|c|c|c|c|c|c|c|}
\hline & $\begin{array}{l}\text { WBC } \\
(\mu / \mathrm{ml})\end{array}$ & PHA & ConA & PWM & $\begin{array}{l}\text { sIL-2R } \\
(\mathrm{U} / \mathrm{ml})\end{array}$ & $\begin{array}{l}\mathrm{CD} 4 / 8 \mathrm{~J} \pm \mathrm{t} \\
(\mu / \mathrm{ml})\end{array}$ & $\begin{array}{l}\text { CD56 }{ }^{+} 16^{+} \text {cell } \\
(\mu / \mathrm{ml})\end{array}$ & $\begin{array}{l}\text { IFN- } \gamma \\
(\mathrm{pg} / \mathrm{ml})\end{array}$ & $\begin{array}{l}\mathrm{NP} \\
(\mathrm{nmol} / \\
\mathrm{mgCr})\end{array}$ \\
\hline \multicolumn{10}{|l|}{ Case $1 M L(62$ y.o. F) } \\
\hline $\begin{array}{l}\text { after } 2 \text { courses of chemo- } \\
\text { therapy and recovery from } \\
\text { bone marrow suppression }\end{array}$ & 3700 & 1.3 & 1.3 & 1.3 & 3680 & 0.2 & & $<0.6$ & 16.83 \\
\hline $\begin{array}{l}\text { after } 3 \text { courses of chemo- } \\
\text { therapy and recovery from } \\
\text { bone marrow suppression }\end{array}$ & 4700 & 2.0 & 1.6 & 1.5 & 2930 & 0.5 & 8.2 & $<0.6$ & 20.50 \\
\hline $\begin{array}{l}\text { after } 3 \text { courses of chemo- } \\
\text { therapy and bone marrow } \\
\text { suppression state }\end{array}$ & 500 & 2.0 & 2.7 & 2.5 & 1470 & 0.5 & 18.8 & $<0.6$ & 12.23 \\
\hline $\begin{array}{l}\text { after high dose chemother- } \\
\text { apy and before PBSCC }\end{array}$ & 2900 & 1.8 & 2.2 & 1.6 & 2990 & 0.6 & 15.2 & $<0.6$ & 14.41 \\
\hline before PBSCT & 300 & & & & & & & $<0.6$ & 10.52 \\
\hline after PBSCT & 100 & & & & 1150 & 0.7 & 7.9 & 5.01 & 11.09 \\
\hline $\begin{array}{l}\text { after PBSCT and recovery } \\
\text { from bone marrow suppres- } \\
\text { sion }\end{array}$ & 2600 & & & & 812 & 0.1 & 7.8 & 1.0 & 14.08 \\
\hline follow up & 1800 & & & & & & & & 10.59 \\
\hline \multicolumn{10}{|l|}{ Case $2 M L(60$ y.o. $M)$} \\
\hline $\begin{array}{l}\text { after chemotherapy and re- } \\
\text { covery from bone marrow } \\
\text { suppression }\end{array}$ & 8900 & & & & 501 & & & & 1.01 \\
\hline $\begin{array}{l}\text { after chemotherapy and re- } \\
\text { covery from bone marrow } \\
\text { suppression }\end{array}$ & 2800 & 1.5 & 1.4 & 1.1 & 617 & 0.4 & & $<0.6$ & 3.31 \\
\hline $\begin{array}{l}\text { after chemotherapy and re- } \\
\text { covery from bone marrow } \\
\text { suppression }\end{array}$ & 2700 & 1.3 & 1.2 & 1.6 & 617 & 0.3 & 3.3 & $<0.6$ & 1.40 \\
\hline terminal & 3700 & & & & 2410 & & & $<0.6$ & 5.89 \\
\hline \multicolumn{10}{|l|}{ Case 3 AML (33 y.o. F) } \\
\hline relapse & 3300 & 3.6 & 3.6 & 1.7 & 185 & 0.8 & 1.3 & $<0.6$ & 0.42 \\
\hline $\begin{array}{l}\text { after re-induction therapy } \\
\text { and bone marrow suppres- } \\
\text { sion state }\end{array}$ & 100 & & & & & & & $<0.6$ & 1.11 \\
\hline $\begin{array}{l}\text { after re-induction therapy } \\
\text { and recovery from bone } \\
\text { marrow suppression }\end{array}$ & 1400 & 2.5 & 3.9 & 1.8 & 191 & 1.5 & 0.7 & $<0.6$ & 1.13 \\
\hline $\begin{array}{l}\text { after re-induction therapy } \\
\text { and bone marrow suppres- } \\
\text { sion state }\end{array}$ & 400 & 6.1 & & & 352 & 1.7 & 0.1 & $<0.6$ & 26.38 \\
\hline $\begin{array}{l}\text { after re-induction therapy } \\
\text { and recovery from bone } \\
\text { marrow suppression }\end{array}$ & 1400 & & & & & & & $<0.6$ & 0.40 \\
\hline $\begin{array}{l}\text { after re-induction therapy } \\
\text { and bone marrow suppres- } \\
\text { sion state }\end{array}$ & 1660 & 2.9 & 2.7 & 1.9 & 237 & 0.9 & 3.4 & $<0.6$ & 20.60 \\
\hline
\end{tabular}




\begin{tabular}{|c|c|c|c|c|c|c|c|c|c|}
\hline \multicolumn{10}{|l|}{ Case 4 AUL (55 y.o. M) } \\
\hline onset & 5000 & 1.0 & 1.0 & 1.0 & 433 & 4.8 & 2.6 & $<0.6$ & 22.20 \\
\hline $\begin{array}{l}\text { after re-induction therapy } \\
\text { and bone marrow suppres- } \\
\text { sion state }\end{array}$ & 400 & 1.1 & 1.1 & 1.1 & 457 & 5 & 2.6 & $<0.6$ & 10.79 \\
\hline $\begin{array}{l}\text { after consolidation therapy } \\
1 \text { and recovery from bone } \\
\text { marrow suppression }\end{array}$ & 3550 & 1.7 & 1.8 & 1.9 & 447 & 1.5 & 17.6 & $<0.6$ & 28.25 \\
\hline $\begin{array}{l}\text { after consolidation therapy } \\
2 \text { and recovery from bone } \\
\text { marrow suppression }\end{array}$ & 2710 & & 2.6 & 1.3 & 586 & 2.5 & 13.2 & & 20.30 \\
\hline $\begin{array}{l}\text { after consolidation therapy } \\
3 \text { and recovery from bone } \\
\text { marrow suppression }\end{array}$ & 2830 & 1.5 & 2.5 & 1.7 & 576 & 2.9 & 10.8 & $<0.6$ & 17.80 \\
\hline \multicolumn{10}{|l|}{ Case 5 AML (66 y.о. $M)$} \\
\hline $\begin{array}{l}\text { after maintenance therapy } \\
5 \text { and recovery from bone } \\
\text { marrow suppression }\end{array}$ & 6600 & 1.2 & 1.1 & 1.0 & 521 & 3.4 & 7.6 & $<0.6$ & 30.20 \\
\hline $\begin{array}{l}\text { after maintenance therapy } \\
6 \text { and recovery from bone } \\
\text { marrow suppression }\end{array}$ & 5540 & 1.3 & 1.5 & 1.3 & 485 & 4.2 & 4.7 & $<0.6$ & 13.50 \\
\hline \multicolumn{10}{|l|}{ Case 6 MM (35 y.o. M) } \\
\hline $\begin{array}{l}\text { after chemotherapy and re- } \\
\text { covery from bone marrow } \\
\text { suppression }\end{array}$ & 5700 & 2.0 & 1.9 & 1.0 & 535 & 1.1 & 15.3 & $<0.6$ & 3.34 \\
\hline $\begin{array}{l}\text { before high dose chemo- } \\
\text { therapy, due to PBSCC }\end{array}$ & 7200 & 3.6 & 2.8 & 2.0 & 318 & 1.3 & 7.7 & $<0.6$ & 0.55 \\
\hline $\begin{array}{l}\text { after high dose chemother- } \\
\text { apy and before PBSCC }\end{array}$ & 12900 & 1.8 & 1.3 & 1.2 & 443 & 1.8 & 4.3 & $<0.6$ & 0.94 \\
\hline after PBSCC & 3800 & 4.0 & 2.8 & 2.1 & 290 & 1.0 & 7.5 & $<0.6$ & 1.30 \\
\hline $\begin{array}{l}\text { after chemotherapy and re- } \\
\text { covery from bone marrow } \\
\text { suppression }\end{array}$ & 3300 & 4.2 & 3.6 & 2.0 & 251 & 1.5 & 19.9 & 0.7 & 1.29 \\
\hline follow up & 3200 & & & & & & & & 1.24 \\
\hline $\begin{array}{l}\text { before high dose chemo- } \\
\text { therapy, due to PBSCT }\end{array}$ & 3500 & 21 & 2.1 & 1.4 & 259 & 0.9 & 9.4 & 4.05 & 24.30 \\
\hline after PBSCT & 8420 & 1.8 & 1.2 & 1.1 & 583 & 0.2 & 8.6 & 1.15 & 30.50 \\
\hline \multicolumn{10}{|l|}{$\begin{array}{l}\text { Case } 7 M M \text { (Plasmacytoma) } \\
(68 \text { y.o. } M)\end{array}$} \\
\hline after tumorectomy & 2500 & 2.4 & 2.5 & 1.8 & 293 & 3.2 & 11.4 & $<0.6$ & 4.17 \\
\hline $\begin{array}{l}\text { after chemotherapy and re- } \\
\text { covery from bone marrow } \\
\text { suppression }\end{array}$ & 6000 & 2.0 & 1.2 & 1.4 & 451 & 2.8 & 15.2 & $<0.6$ & 5.71 \\
\hline $\begin{array}{l}\text { after chemotherapy and re- } \\
\text { covery from bone marrow } \\
\text { suppression }\end{array}$ & 2650 & 2.6 & 2.4 & 2.8 & 421 & 1.5 & 16.5 & $<0.6$ & 2.39 \\
\hline
\end{tabular}

possible that the marked variation of urine NP levels may be due to the immunological conditions of the host. Serum sIL-2R is considered to be a marker for $\mathrm{T}$ cell activation [10]. The significant elevation of sIL-2R in the patients with ML indicates that $\mathrm{T}$ cell activa- tion was triggered by the pathological state of ML. Thus the correlation between urine NP and serum sIL-2R in the patients with ML suggests that urine NP is released from activated T cells. The parallel variation of urine NP with serum sIL-2R in the patients with ML raised 
$\mathrm{ML}$

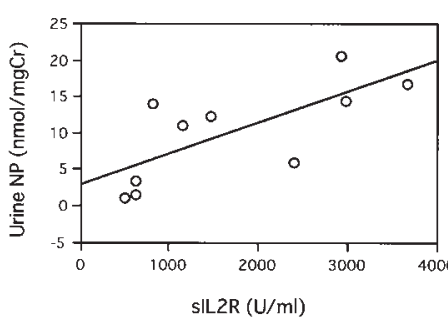

$r=0.718$

$p=0.0194$

$n=10$

$Y=2.972+0.004 * X_{*} R \wedge 2-0.51$

AML

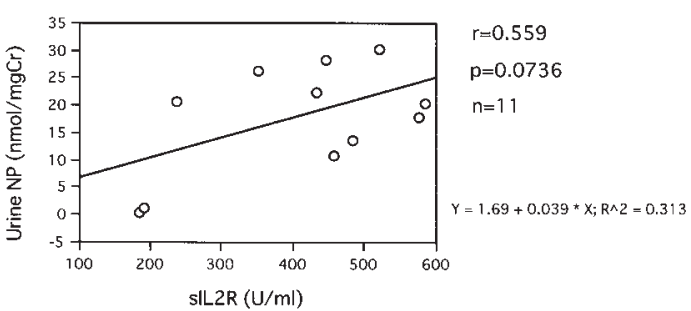

MM

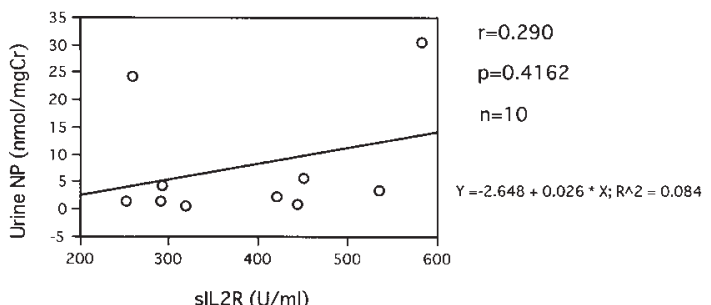

Figure 1. Correlation between urine neopterin (NP) and serum SIL-2R in patients with malignant lymphoma (ML), acute myelocytic leukemia (AML) and multiple myeloma (MM).

the possibility that urine NP can be an index for $\mathrm{T}$ cell activation in the patients with ML.

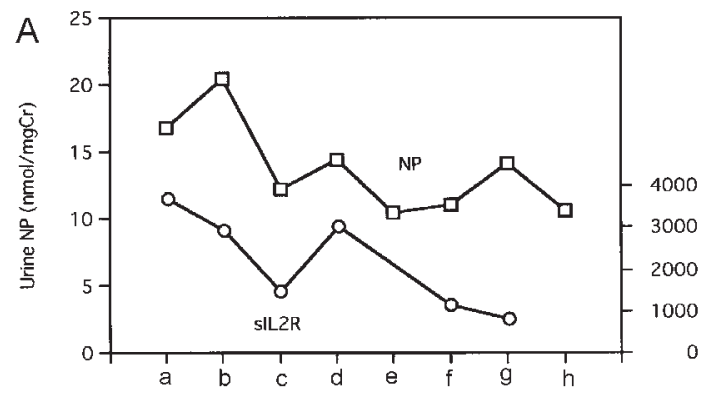

ML

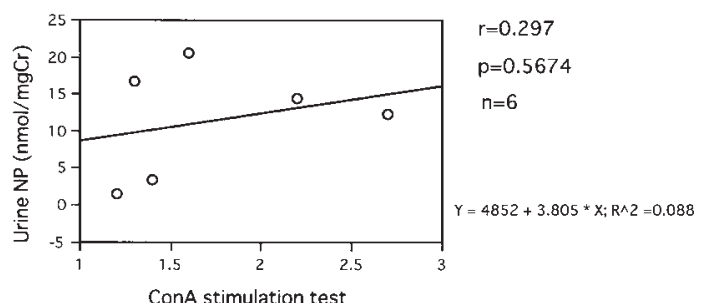

AML

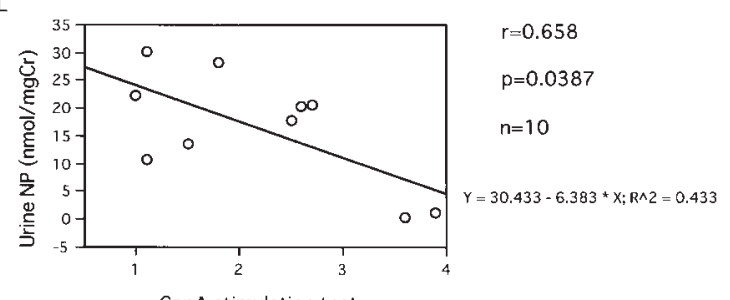

MM

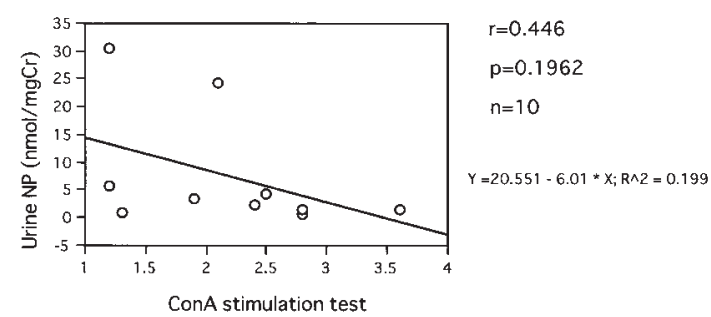

Figure 2. Correlation between urine neopterin (NP) and lymphocyte reaction with ConA in patients with malignant lymphoma (ML), acute myelocytic leukemia (AML) and multiple myeloma (MM).

In the patients with AML and MM, no correlation was observed between urine NP and se-

B

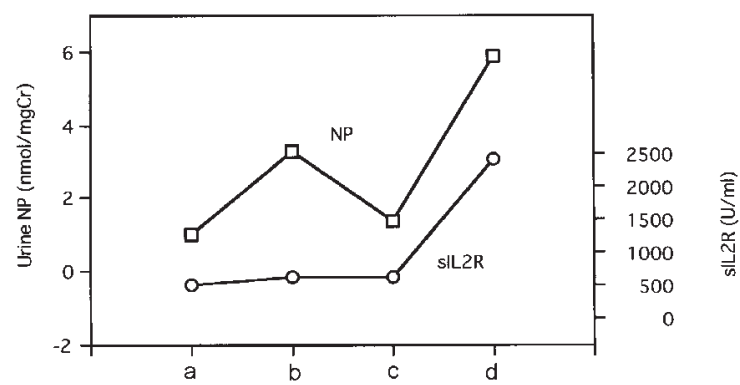

Figure 3. Profile of urine neopterin and serum sIL-2R in patients with multiple myeloma (ML).

A. Case 1: a, after 2 courses of chemotherapy and recovery from bone marrow suppression; b, after 3 courses of chemotherapy and recovery from bone marrow suppression; c, after 4 courses of chemotherapy and bone marrow suppression state; d, after high dose of chemotherapy and before PBSCC; e, before PBSCT; f, after PBSCT; g, after PBSCT and recovery from bone marrow suppression; h, follow up. B. Case 2: a, after chemotherapy and recovery from bone marrow suppression; b, after chemotherapy and recovery from bone marrow suppression; c, after chemotherapy and recovery from bone marrow suppression; $d$, terminal. 
rum sIL-2R. In these patients, sIL-2R levels varied within the normal range. Thus it is assumed that urine NP levels are not as sensitive as the level of sIL-2R to T cell activation. The lymphocyte reaction with ConA is also a marker for T cell activation. From our data, the inverse correlation between urine NP and lymphocyte reaction with ConA in the patients with AML cannot be easily explained. Since no relationship was observed between the profile of urine NP and lymphocyte reaction with ConA in the patients with AML, urine NP is possibly affected by some factors other than $\mathrm{T}$ cell activation in AML. Taken together, these results suggest that urine NP level is correlated with the activation of T cells in some hematological disorders.

\section{R E F E R E N C ES}

1. Brune, B., Götz, C., Mesmer, U.K., Sandau, K., Hirvonen, M.-R. \& Lapetina, E.G. (1997) Superoxide formation and macrophage resistance to nitric oxide-mediated apoptosis. J. Biol. Chem. 272, 7253-7258.

2. Evans, T.J., Buttery, L.D.K., Carpenter, A., Springall, D.R., Polak, J.M. \& Cohen, J. (1996) Cytokine-treated human neutrophils contain inducible nitric oxide synthase that produces nitration of ingested bacteria. Proc. Natl. Acad. Sci. U.S.A. 93, 9553-9558.

3. Filep, J.G., Baron, C., Lachance, S., Perreault, C. \& Chan, J.S.D. (1996) Involvement of nitric oxide in target-cell lysis and DNA fragmentation induced by murine natural killer cells. Blood 87, 5136-5143.

4. Werner, E.R., Werner-Felmayer, G., Fuchs, D., Hausen, A., Reibnegger, G., Yim, J.J., Pfleiderer, W. \& Wachter, H. (1990) Tetrahydrobiopterin biosynthetic activities in hu- man macrophages, fibroblasts, THP-1, and T 24 cells. J. Biol. Chem. 265, 3189-3192.

5. Ziegler, I., Schott, K., Lubbert, M., Herrmann, F., Schwulera, U. \& Bacher, A. (1990) Control of tetrahydrobiopterin synthesis in T lymphocytes by synergistic action of interferon- $\gamma$ and interleukin-2. J. Biol. Chem. 265, 1702617030 .

6. Lim, K.L., Muir, K. \& Powell, R.J. (1994) Urine neopterin: A new parameter for serial monitoring of disease activity in patients with systemic lupus erythematosus. Ann. Rheum. Dis. 53, 743-748.

7. Huber, C., Batchelor, J.R., Fuchs, D., Hausen, A., Lang, A., Niederwieser, D., Reibnegger, G., Swethy, P., Troppmair, J. \& Wachter, H. (1984) Immune response-associated production of neopterin: Release from macrophages primarily under control of interferon-gamma. J. Exp. Med. 160, 310-316.

8. Hibiya, M., Teradaira, R., Sugimoto, T., Fujita, K. \& Nagatsu, T. (1995) Simultaneous determination of $N^{2}$-(3-aminopropyl)biopterin (oncopterin), biopterin and neopterin by high-performance liquid chromatography with fluorescence detection. J. Chromatogr. B 672, 143148.

9. Satoh, T., Brown, L.M., Blattner, W.A., Maloney, E.M., Kurman, C.C., Nelson, D.L., Fuchs, D., Wachter, H. \& Tollerud, D.J. (1998) Serum neopterin, $\beta_{2}$-microglobulin, soluble interleukin-2 receptors, and immunoglobulin levels in healthy adolescents. Clin. Immunol. Immunopathol. 88, 176-182.

10. Rubin, L.A., Kurman, C.C., Fritz, M.E., Biddison, W.E., Boutin, B., Yarchoan, R. \& Nelson, D.L. (1985) Soluble interleukin 2 receptors are released from activated human lymphoid cells in vitro. J. Immunol. 135, 3172-3177. 